\title{
ANTIBACTERIAL EFFECTIVENESS OF SELECTED MOROCCAN ESSENTIAL OILS AGAINST THE HIGHLY VIRULENT JP2 CLONE OF AGGREGATIBACTER ACTINOMYCETEMCOMITANS
}

\author{
LEILA LAKHDAR, ABDELLAH FARAH, IDRISS LAHLOU, SANA RIDA, AMAL BOUZIANE, OUMKELTOUM ENNIBI
}

\author{
Faculty of Dental Medicine, Mohammed V University in Rabat Morocco
}

Email: leila.lakhdar@gmail.com

Received: 10 Jun 2016 Revised and Accepted: 07 Dec 2016

\begin{abstract}
Objective: Aggregatibacter actinomycetemcomitans ( $A a)$ serotype b JP2 clone is a highly virulent strain, considered as a major etiologic agent in aggressive periodontitis in patients of African descent, such as Moroccan adolescents. Antibiotics have been and continue to be the only effective treatment of periodontal infections caused by this periodontal bacterium. However, today there is enough scientific evidence on the existence of an increased resistance of oral bacteria to antibiotics. Therefore, the search for new natural agents, that are safe and effective, such "essential oils," has become a necessity. The present study was conducted to evaluate the in vitro antibacterial activities of three selected essential oils from Moroccan aromatic medicinal plants (Origanum compactum, Thymus vulgaris and Cymbopogon martinii) against clinical Moroccan isolate of Aa JP2 strain.
\end{abstract}

Methods: Antibacterial activity of essential oils was investigated using agar well diffusion method, then measured using broth microdilution method.

Results: All the selected essential oils exhibited significant antibacterial activity on the highly pathogenic JP2 strain of Aa. Essential oil of Origanum compactum was found to be the most effective with a minimum inhibitory concentration (MIC) value of $0.03 \%$ (v/v) and a minimum bactericidal concentration value (MBC) of $0.07 \%$

Conclusion: The present findings indicate the possibility of exploiting these essential oils as potential antimicrobial agents in treatment of aggressive periodontitis associated to this pathogen.

Keywords: Oral bacteria, Aggregatibacter actinomycetemcomitans, Essential oils, Antimicrobial activity, Minimum inhibitory Concentration

(C) 2017 The Authors. Published by Innovare Academic Sciences Pvt Ltd. This is an open access article under the CC BY license (http://creativecommons.org/licenses/by/4. 0/) DOI: http://dx.doi.org/10.22159/ijpps.2017v9i2.13406

\section{INTRODUCTION}

The oral species Aggregatibacter actinomycetemcomitans (Aa) is a period onto pathogen, known as strongly associated with aggressive periodontitis, severe periodontal diseases which lead to rapid destruction of supporting tissues of teeth in young adults [1-3]. Genome analysis revealed that this species comprises discrete clonal lineages represented by different serotypes (a, b, c, d, e, f) associated with periodontitis or health, which may help to explain their differences in virulence and in association with disease [4-6]. Serotype b strain with a 530-bp deletion in the promoter region of the leukotoxin operon is designated as JP2 clone. This particular strain was found to be strongly associated with aggressive periodontitis in patients of African descent such as Moroccan adolescents [7]. The main characteristic of the virulent clone (JP2) is the expression of high levels of leukotoxin [8]. Consequently, the eradication of this bacterium is essential, based upon mechanical treatment of periodontal pockets associated to antibiotics. However, nowadays, there is sufficient evidence that antibiotic resistance has increased in the periodontal flora. Thus, the use of natural products such as essential oils, to overcome antibacterial resistances [9] and side effects of synthetic drugs, could be a good alternative as a new adjunctive treatment against this periopathogen. Moreover, these last decades, trials have shown the benefits of natural products on oral health and oral pathogens $[10,11]$. In this study, we selected 3 Moroccan essential oils from Origanum compactum, Thymus vulgaris and Cymbopogon martinii, well known for their use in folk medicine and their antimicrobial effect on various extra oral bacteria and fungus [12-19], in order to evaluate their antibacterial activities against the highly pathogenic JP2 strain of $A a$.

\section{MATERIALS AND METHODS}

\section{Bacterial strains and growth conditions}

A Moroccan clinical isolate ( $A a$ serotype b, JP2 clone), obtained from Kyushu Dental College, Japan was used in this study. This strain was originally isolated from sampling of subgingival plaque in patients with aggressive periodontitis, at the Department of Periodontology, at the Center of Counseling and dental treatment in Rabat, Morocco. The bacterium was maintained by cultivation on chocolate agar with Vitox (Oxoid Deutschland Gmbh, Postfach, Wesel) or brain heart infusion (BHI) agar (Oxoid Ltd, Wade Road, Basingstoke, Hants, UK), under an atmosphere of $5 \% \mathrm{CO}_{2}$ at $37{ }^{\circ} \mathrm{C}$ for $48 \mathrm{~h}$.

\section{Essential oils}

Three essential oils derived respectively from Origanum compactum (oregano), Thymus vulgaris (thyme) and Cymbopogon martinii (palamarosa), were tested in this assay. These oils were kindly provided by the National Institute of Medicinal and Aromatic Plants, Taounate, Morocco. They were extracted from plants, which were grown in the experimental garden of the institute. The Botanical identification was done by $\mathrm{F}$ A. and the authenticated voucher specimens were deposited in the Herbarium of photochemistry laboratory of the National Institute of Medicinal and Aromatic Plants-University of Sidi Mohamed Ben Abdellah, Fez, Morocco. Codes were assigned to different samples: Origanum compactum (code: FA/RP/INPMA/107), Thymus vulgaris (code: FA/RP/ INPMA/108), Cymbopogon martinii (code: FA/RP/INPMA/109). The choice of essential oils was based on their documented antimicrobial effects and/or on anecdotal use in the population [20-23]. (table 1).

\section{Essential oils extraction}

A portion (100 g) of the aerial parts of the plants was hydrodistilled, for at least three hours, using a Clevenger-type apparatus. To eliminate any traces of water, the extracted oil was treated with anhydrous sodium sulfate $\left(\mathrm{Na}_{2} \mathrm{SO}_{4}\right)$, filtered and then stored in the dark at $4^{\circ} \mathrm{C}$. Chromatographic analysis and characterization of oils.

Essential oils were analyzed by gas chromatography (GC) and gas chromatography coupled with mass spectrometry (GC/MS). Gas chromatography analyses were performed on a Hewlett-Packard 
(HP 6890) gas chromatograph (FID), equipped with a HP-5 capillary column ( $5 \%$ phenyl methyl silicone). The characteristic of this column was: $30 \mathrm{~m}$ of length, $0.25 \mathrm{~mm}$ of diameter and $0.25 \mu \mathrm{m}$ of film thickness. The temperature was programmed from $50{ }^{\circ} \mathrm{C}$ (initial waiting $5 \mathrm{~min}$ ) to $200{ }^{\circ} \mathrm{C}$ at $4{ }^{\circ} \mathrm{C} / \mathrm{min}$. Gas chromatography conditions were as follows: $\mathrm{N}_{2}$ as carrier gas $(1.8 \mathrm{ml} / \mathrm{min})$; split mode (Flow: $72.1 \mathrm{ml} / \mathrm{min}$, ratio: $1 / 50$ ) was used; temperatures of injector and detector were $275{ }^{\circ} \mathrm{C}$ and $250{ }^{\circ} \mathrm{C}$ respectively. Diluted samples $(1 / 20$ in Hexane) of $1 \mu \mathrm{l}$ were injected manually. The machine was run by a computer system type "HP ChemStation". Gas chromatography coupled with mass spectrometry (GC/MS): The chemical composition of essential oils was analyzed using a gas chromatograph (TRACE GC Ultra) fitted to a mass spectrometer (Polaris Q-Ion Trap MS). Operating in electron-impact EI $(70 \mathrm{eV})$ mode. VB-5 (Methylpolysiloxane $5 \%$ phenyl) and a column $(30 \mathrm{~m} \times$ $0.25 \mathrm{~mm} \times 0.25 \mu \mathrm{m}$ thickness) were used (National Centre of Scientific and Technical Research-(NCSTR), Rabat, Morocco). The chromatographic conditions were as follows: Injector and detector temperatures at 220 and $300{ }^{\circ} \mathrm{C}$ respectively; carrier gas, helium at flow rate of $1.4 \mathrm{ml} / \mathrm{min}$; temperature program ramp from 40 to $300{ }^{\circ} \mathrm{C}$ with gradient of $4{ }^{\circ} \mathrm{C} / \mathrm{min}$ (holding the initial and final temperature for $4 \mathrm{~min}$ ). The relative amount of individual components of the total oil was expressed as a percentage peak area relative to total peak area. Library search was carried out using the combination of NIST MS Search and literature. Oils constituents were also identified by their retention indices relatives to n-alkanes (C8-C24).

\section{In vitro antimicrobial assay}

\section{- Agar well-diffusion method}

The antibacterial activity of the selected Moroccan essential oils was evaluated by agar well-diffusion method. Initially, each tested essential oil was dissolved in Tween 80/water (1/9). Inoculate of micro-microorganisms was prepared by growing organisms on slant cultures for $24 \mathrm{~h}$, and suspending colonies in a sterile solution of $0.85 \% \mathrm{NaCl}$. Suspensions were adjusted to the turbidity of a 0.5 McFarland standards (approx. $1 \times 10^{8} \mathrm{CFU} / \mathrm{ml}$ ). At first, the liquid bacterial culture was spread onto plates as described by Dorman and Deans 2000 [24]. After 15 min, the essential oil was poured in wells $(6 \mathrm{~mm}$ diameter) made in the center of each agar plate. Doxycycline (disc: $30 \mu \mathrm{g}$ ) was used as positive control. Negative control consisted of $10 \%$ Tween 80 , which was used to dissolve the essential oils. All tests were performed in triplicate. The plates were incubated at $37^{\circ} \mathrm{C}$ in atmosphere of $5 \% \mathrm{CO}_{2}$ for $48 \mathrm{~h}$.

- Determination of minimum inhibitory concentration (MIC) and minimum bactericidal concentration (MBC)

The MICs of the respective essential oils against $A a$ JP2 clone were determined according to a modification of the method described by
Shapiro et al. 1994 [25]. The test was determined in sterile 96-well microplates with a final volume in each microplate well of $200 \mu$ l. BHI broth was used for the strain of $A a$. The turbidity of each liquid culture for use in the assays was adjusted to 0.5 McFarland Units (approx. $1 \times 10^{8} \mathrm{CFU} / \mathrm{ml}$ ) using sterile BHI. Then, two fold serial dilutions of each original sample of essential oil were prepared in sterile culture medium to produce the concentration range of $(1,25 \%-0,019 \%)$. Aliquots $(100 \mu \mathrm{l})$ of each dilution were dispensed into each well of 96-well cell culture plates with $100 \mu \mathrm{l}$ of liquid culture. Amoxicillin $(10 \mathrm{mg} / \mathrm{ml})$ was used as positive control, Tween $80 /$ water (1/9) as negative control. The plates were covered with plastic lids and incubated at $37^{\circ} \mathrm{C}$ for $48 \mathrm{~h}$ under $5 \% \mathrm{CO}_{2}$.

The determination of MIC values was done in triplicate and tests were duplicated. After incubation period, $40 \mu \mathrm{L}$ of a $2 \mathrm{mg} / \mathrm{ml}$ Triphenyl tetrazolium chlorid (TTC) indicator solution (indicator of microorganism growth) was added to every well and the plate was incubated at $37{ }^{\circ} \mathrm{C}$ for about $2 \mathrm{~h}$ [26]. The TTC indicator solution changes from clear to purple in the presence of bacterial activity. Whereas it remains clear when microbial growth was inhibited. MIC was defined as the lowest concentration of essential oil that showed no visible bacterial growth after incubation time (no color change (clear) of TTC). To determine the MBC, $10 \mu \mathrm{L}$ aliquots of cultures were taken from wells showing no visible turbidity, inoculated onto chocolate agar plates and incubated for $48 \mathrm{~h}$ at $37^{\circ} \mathrm{C}$ under $5 \% \mathrm{CO}_{2}$ [27]. The MBC was considered as the lowest concentration of essential oil that killed $99.9 \%$ of microorganisms in culture on the agar plate after incubation period. This experiment (determination of MBC values) was performed in triplicate. The MBC/MIC ratio was also calculated to exhibit the nature of antibacterial effect of essential oils. When the ratio was lower than 4 , the essential oil was considered as a bactericidal essential oil and when the ratio was higher than 4 , it was considered as a bacteriostatic essential oil [28].

\section{Statistical analyses}

Inhibition zone diameter, a continuous variable with a normal distribution, was presented as mean \pm standard deviation. For statistical differences between the four groups (Origanum compactum, Thymus vulgaris, Cymbopogon martinii, Doxycycline), the One Way Analysis Of Variance (ANOVA) with Bonferroni correction was performed. $\mathrm{P}$ value $<0.05$ was considered as statistically significant. MIC (\%) (v/v), MBC (\%) and the MBC/MIC ratio were expressed as mean \pm standard deviation (SD). For statistical differences between the three tested essential oils concerning these variables, the One Way Analysis Of Variance (ANOVA) with Bonferroni correction was used. $\mathrm{P}$ value $<0.05$ was considered as statistically significant. Statistical analyses were carried out using SPSS for Windows (SPSS, Inc., Chicago, IL, USA).

Table 1: Moroccan essential oils tested in this study and their medicinal properties in traditional use

\begin{tabular}{llll}
\hline Common name & Species & Family plant & Medicinal properties \\
\hline Oregano & Origanum compactum & Lamiaceae & Intestinal antiseptic, diuretic, antacid, stomachic, antispasmodic.[20] \\
Thyme & Thymus vulgaris & Lamiaceae & Pulmonary and intestinal antiseptic, expectorant, diuretic, stomachic, anthelmintic, \\
& & antispasmodic.[20] & Insect repellent [21] anthelmintic [22] antifungal [23]. \\
Palmarosa & Cymbopogon martinii & Poaceae & .
\end{tabular}

\section{RESULTS}

\section{Chemical composition}

The chemical analyses showed that the major constituents of essential oils tested were as follow: $\gamma$-terpinene $(25.11 \%)$, Carvacrol (22.29\%), Thymol (19.21\%), p-cymene (18.68\%) for Origanum compactum, Thymol (42.01\%), P-Cymene (14.34\%), $\gamma$-Terpinene (12.04\%), Carvacrol (5.07\%) for Thymus vulgaris, Geraniol 84,12\%, Geranyl acetate (6,67\%) for Cymbopogon martinii (table 2).

\section{Antibacterial activity}

\section{- Agar well-diffusion assay}

After incubation time, all the tested essential oils and positive control (Doxycycline) resulted in consistent inhibition zones against
Aa JP2 strain (table 3). No inhibition zone was observed for the negative control $(10 \%$ Tween 80$)$. The difference was statistically significant $(\mathrm{P}$ value $<0,001)$ between the negative control and all the tested agents (Origanum compactum, Thymus vulgaris, Cymbopogon martini and Doxycycline).

\section{- MIC and MBC values determination}

The serial diffusion assay in 96-well microplates revealed MICs values ranged from 0.03 to $0.07 \%(\mathrm{v} / \mathrm{v})$ (table 4). Origanum compactum showed the most significant antibacterial effect on $A a$ with a MIC value of $0,03 \%$. Concerning MBC, the values were ranged from 0.07 to $0.15 \%(\mathrm{v} / \mathrm{v})$.

For MBC/MIC ratio, all the values found were lower than 4, considering thus tested essential oils as bactericidal agents. 
Table 2: Chemical composition of tested essential oils

\begin{tabular}{|c|c|c|c|c|}
\hline $\mathbf{R I}$ & Constituents & Origanum compactum & Thymus vulgaris & Cymbopogon martini \\
\hline 931 & $\alpha$-Thujene & 2.10 & 0.22 & 0,05 \\
\hline 939 & $\alpha$-Pinene & 0.54 & 1.87 & 0.14 \\
\hline 948 & Camphene & 0.17 & - & 0.07 \\
\hline 973 & Sabinene & 0.23 & - & 0.09 \\
\hline 980 & $\beta$-Pinene & 0.16 & 0.79 & 0.06 \\
\hline 991 & Myrcene & 2.21 & 2.18 & 0.34 \\
\hline 999 & $\delta$-2-carene & 0.09 & - & - \\
\hline 1005 & $\alpha$-Phellandrene & 0.26 & 0.51 & - \\
\hline 1011 & $\square$ 2-Carene & 0,08 & - & 0,08 \\
\hline 1018 & $\alpha$-Terpinene & 2.79 & 2.04 & 0.09 \\
\hline 1026 & p-cymene & 18.68 & 14.34 & - \\
\hline 1031 & Limonene & - & 1.01 & 0.28 \\
\hline 1033 & 1,8-cineole & - & 0.82 & - \\
\hline 1044 & b-Ocimene & - & - & 0.86 \\
\hline 1050 & $\beta$-E-ocimene & 0.09 & - & - \\
\hline 1062 & $\gamma$-Terpinene & 25.11 & 12.04 & - \\
\hline 1067 & Cis-hydrate sabinene & 0.15 & - & - \\
\hline 1068 & Cis-sabinen hydrate & - & 0.05 & - \\
\hline 1080 & m-cymenene & 0,14 & - & - \\
\hline 1088 & Terpinolene & 0.07 & 0.78 & - \\
\hline 1098 & Linalool & 1.24 & 4.41 & 2.42 \\
\hline 1143 & Camphor & 0.05 & - & - \\
\hline 1165 & Borneol & 0.20 & - & - \\
\hline 1177 & Terpinen-4-ol & 0.34 & 1.08 & - \\
\hline 1184 & $\rho$-cymen-8-ol & 0.09 & - & - \\
\hline 1189 & $\alpha$-terpineol & 0.99 & - & - \\
\hline 1228 & Nerol & - & - & 0.13 \\
\hline 1235 & Thymol methyl ether & - & 2.14 & - \\
\hline 1240 & Neral & - & - & 0.21 \\
\hline 1255 & Geraniol $\square$ & - & - & 84.12 \\
\hline 1270 & Geranial & - & - & 2.16 \\
\hline 1290 & Thymol & 19.21 & 42.01 & - \\
\hline 1298 & Carvacrol & 22.29 & 5.07 & - \\
\hline 1352 & Terpinyl acetate & & 0.41 & \\
\hline 1356 & Eugenol & - & 0.41 & - \\
\hline 1383 & Geranyl acetate & - & - & 6.67 \\
\hline 1391 & $\beta$-Elemene & - & 0.15 & - \\
\hline 1401 & Methyl Eugenol & - & 0.41 & - \\
\hline 1418 & $\beta$-Caryophyllene & 1.03 & 0.82 & - \\
\hline 1430 & $\beta$-copaene & - & 0.16 & - \\
\hline 1454 & $\alpha$-Humlene & - & 0.26 & - \\
\hline 1480 & Germacrene D & - & 0.34 & - \\
\hline 1509 & $\beta$-Bisabolene & - & 0.37 & - \\
\hline 1513 & $\gamma$-cadinene & 0.05 & - & - \\
\hline 1581 & Caryophyllene oxide & 0.06 & 0.32 & 0.64 \\
\hline
\end{tabular}

RI: Retention Index /values are expressed in percentage.

Table 3: Mean diameter of inhibition zones $(\mathrm{mm})$ obtained by the agar diffusion method

\begin{tabular}{llllcr}
\hline & $\begin{array}{l}\text { Origanum } \\
\text { compactum }\end{array}$ & Thymus vulgaris & $\begin{array}{l}\text { Cymbopogon } \\
\text { martinii }\end{array}$ & $\begin{array}{l}\text { Doxycycline } \\
\text { Tween 80 } \\
(\mathbf{1 0} \%)\end{array}$ \\
\hline Inhibition zone diameter $(\mathrm{mm}) \dagger$ & $17.67 \pm 2.08$ & $18.67 \pm 1.15$ & $22.67 \pm 1.52$ & $22.67 \pm 1.15$ & $6 \pm 0.00 * \circ$ \\
\hline
\end{tabular}

Values are given as mean \pm SD of triplicate experiment, $\dagger$ : diameter of inhibition zones including diameter of well 6 mm. *: diameter of well ( 6 mm). ${ }^{\circ}$ : $\mathrm{P}<0.001$ : Tween 80 (10\%) Vs Origanum compactum, Thymus vulgaris, Cymbopogon martinii and Doxycycline.

Table 4: Minimum Inhibitory Concentrations (MIC)(\%) (v/v) and Minimum Bactericidal Concentrations (MBC) (\%) (v/v) of essential oils against $A a$ JP2 strain

\begin{tabular}{llll}
\hline & Origanum compactum & Thymus vulgaris & Cymbopogon martinii \\
\hline MIC (\%) & $0.03 \pm 0.01$ & $0.06 \pm 0.01$ & $0.05 \pm 0.01$ \\
MBC (\%) & $0.07 \pm 0$ & $0.15 \pm 0$ & $0.07 \pm 0$ \\
MBC/MIC & $2.4 \pm 0.97^{\circ} \circ$ & $2.4 \pm 0.69{ }^{\circ}$ & $1.26 \pm 0.41$ \\
\hline
\end{tabular}

$\mathrm{n}=6$; Values are given as mean $\pm \mathrm{SD}$. MIC and MBC values are expressed in percentage (\%). Data were analyzed by one-way ANOVA., ${ }^{\circ}$ : $<<0.05$ : Thymus vulgaris Vs Cymbopogon martinii $(\mathrm{P}=0.008)^{\circ}{ }^{\circ}: \mathrm{P}<0.05$ : Origanum compactum Vs Cymbopogon martinii $(\mathrm{P}=0.008)$. 


\section{DISCUSSION}

In this study, the obtained results exhibited a potent antibacterial effect of three selected essential oils on a highly virulent periopathogen; JP2 clone of $A a$. Actually, we tested selected Moroccan essential oils (Origanum compactum, Thymus vulgaris and Cymbopogon martinii), which have never been studied on oral bacteria especially on the highly JP2 strain of $A a$, a gram-negative facultative anaerobic bacterium and a well-known periopathogen strongly involved in aggressive periodontitis [1-3]. The choice of essential oils was based on their documented medicinal properties particularly antimicrobial effects and/or on their therapeutic use in traditional medicine in Moroccans (table 1). Indeed, Origanum compactum and Thymus vulgaris, belonging to plant family of Lamiaceae, is widely used for their antimicrobial properties $[29,30]$. And Cymbopogon martinii, from plant family of poacea, is mainly known for its insecticidal and antiseptic properties [21-23]. The in vitro antibacterial activity of these tested essential oils against $A a$ JP2 strain was qualitatively and quantitatively assessed by the presence of inhibition zone diameters and MIC and MBC values. As shown in table 3 and 4, all tested essential oils exhibited good antibacterial activity against the studied microorganism. The inhibition zones were in range of 17.67-22.67 $\mathrm{mm}$, which demonstrated a good susceptibility of the tested bacterium to the selected essential oils. Indeed, as showed by Durrafourd et al. [31], a tested microorganism is considered not sensitive for a diameter smaller than $8 \mathrm{~mm}$, moderately sensitive for a 8-14 mm diameter, sensitive for a $14-20 \mathrm{~mm}$ diameter, and very sensitive for a diameter larger than $20 \mathrm{~mm}$. The significant antimicrobial activity of all these tested oils could be attributed to its major components. Indeed, the obtained results showed that Origanum compactum was dominated by phenols (thymol $19.21 \%$ et carvacrol $22.29 \%$ ), which are known responsible of bactericidal activity of essential oils [32,33]. Thymol is also present at high concentration (42.01\%) in Thymus vulgaris which would also explain the potent antimicrobial activity of this tested oil, as reported in an anterior study [34]. Actually, in a previous report, Thymol showed significant antibacterial effect on Aa [25]. Cymbopogon martinii was characterized by the dominance of alcohols such as Geraniol (84.12\%). This chemical constituent could be at the origin of its marked antibacterial efficacy, because of their high antimicrobial activity demonstrated in previous studies $[35,36]$. Indeed, according to the literature, alcohols and phenols are well known for their antimicrobial efficacy more than other chemical compounds (such as terpene hydrocarbons) [24, 37, 38].

Concerning the 96-well microplates assay (MIC and MBC values determination), Origanum compactum has been found to be the most active oil with the highest inhibitory (MIC of $0.03 \%$ ) and bactericidal activity (MBC of $0.07 \%$ ) in comparison with other tested oils (Thymus vulgaris and Cymbopogon martini). These results are in agreement with those obtained in previous works on other tested nonoral Gram-negative bacteria [39-42]. Essential oils of Thymus vulgaris and Cymbopogon martinii exhibited MIC of $0.06 \%$ and $0.05 \%$ respectively, reflecting also a strong antibacterial activity on $A a$. These findings confirm those found in the literature on other extraoral bacteria [27, 41]. More recently, Kedzia et al. 2013 [43], tested Thymus vulgaris on $A a$ and reported a potent antimicrobial effect of this oil on Aa (MICs $\leq 62-500 \mathrm{ug} / \mathrm{ml}$ ). Otherwise, the CMB/CMI ratio was calculated in this study, providing information on the nature of the antibacterial effect of tested essential oils [28]. All the studied essential oils have been found to be bactericidal on $A a$ JP2 strain. However, some statistical differences have been registered between both Origanum compactum and Thymus vulgaris with Cymbopogon martinii (table 4). This may be probably related to chemical composition relative to each tested oils. Indeed, as we mentioned above, phenols, as major compound of Origanum compactum and Thymus vulgaris (but not found in Cymbopogon martinii), are well known responsible of bactericidal activity of essential oils [32,33].

In our study, it is worth noting that this virulent oral pathogen $(A a$ JP2 strain) was a clinical isolate, sampled from subgingival biofilm in periodontitis patients. Earlier studies have demonstrated significant inhibitory activity of similar tested essential oils (Origanum compactum, Thymus vulgaris and Cymbopogon martinii) against other various clinical isolates of different origins (respiratory, intestinal...). Indeed, Cymbopogon martinii proved to be potent in inhibition of pathogenic Gram negative bacteria, clinically isolated from vaginal infections, as reported by Schwiertz et al. 2006 [44]. Similarly, Thymus vulgaris showed antibacterial activity against clinical isolates of the respiratory tract including facultative anaerobic Gram negative species (Haemophilus influenzae) [45]. Origanum compactum, in previous studies, also showed antibacterial efficacy on clinical isolates of Gram-negative bacteria of intestinal, respiratory and skin origins $[19,42]$. Thus, it should be noted that although clinical isolates belong to bacterial biofilm, and may develop antimicrobial resistance such as acquired resistance to antibiotics which is often reported, no particular bacterial resistance or adaptation to these essential oils has been described in all these tested clinical isolates. This may be probably related to the mode of action of essential oils affecting several targets of bacterial structures at the same time [46]. Therefore, according to our obtained results, the highly leukotoxic clone (JP2) of $A a$ has been shown to be very sensitive to natural agents; three selected essential oils (Origanum compactum, Thymus vulgaris and Cymbopogon martinii). However, the evaluation of the safety and toxicity of these products is still required. Otherwise, the tested microorganism (JP2 $A a$ ) is a virulent periodontal pathogen growing within a biofilm in patients with periodontal infections. This biofilm is composed of other various and complex periopathogens, which are also associated with aggressive periodontitis. Thus, further in vitro and in vivo studies are needed to evaluate the antimicrobial activity of these selected essential oils on the entire subgingival biofilm sampled from periodontitis patients, in order to consider the possibility of exploiting these new natural products as effective antibacterial agents in the treatment of aggressive periodontitis.

\section{CONCLUSION}

This in vitro study showed sensitivity of the highly virulent JP2 clone of $A a$ to the selected essential oils; Origanum compactum, Thymus vulgaris and Cymbopogon martinii. Based on these findings, we could suggest the usefulness of these natural products as potential antimicrobial agents in periodontal diseases associated to this virulent microorganism.

\section{ACKNOWLEDGMENT}

The authors are thankful to Prof. Akihiro Yoshida from Kyushu Dental University of Japan for providing $A a$ JP2clone. And also, the Mohammed V University of Rabat for the sponsorship of the study.

\section{CONFLICT OF INTERESTS}

All the author(s): Lakhdar Leila, Farah Abdellah, Idriss Lahlou Amine, Sana Rida, Amal Bouziane and Oumkeltoum Ennibideclare that there is no conflict of interest regarding the publication of this paper.

\section{REFERENCES}

1. Haubek D, Ennibi OK, Poulsen K, Poulsen S, Benzarti N, Kilian M. Early-onset periodontitis in Morocco is associated with the highly leukotoxic clone of Actinobacillus actinomycetemcomitans. J Dent Res 2001;80:1580-3.

2. Haubek D, Ennibi OK, Poulsen K, Vaeth M, Poulsen S, Kilian M. Risk of aggressive periodontitis in adolescent carriers of the JP2 clone of Aggregatibacter (Actinobacillus) actinomycetemcomitans in Morocco: a prospective longitudinal cohort study. Lancet 2008;371:237-42.

3. Ennibi OK, Benrachadi L, Bouziane A, Haubek D, Poulsen K. The highly leukotoxic JP2 clone of Aggregatibacter actinomycetemcomitans in localized and generalized forms of aggressive periodontitis. Acta Odontol Scand 2012;70:318-22.

4. Kaplan JB, Schreiner HC, Furgang D, Fine DH. Population structure and genetic diversity of Actinobacillus actinomycetemcomitans strains isolated from localized juvenile periodontitis patients. J Clin Microbiol 2002;40:1181-7.

5. Rylev M, Kilian M. Prevalence and distribution of principal periodontal pathogens worldwide. J Clin Periodontol 2008;35:346-61.

6. Emiko Umeda J, Larcher Longo P, Lorenzetti Simionato MR, Pinto Alves Mayer M. Differential transcription of virulence genes in Aggregatibacter actinomycetemcomitans serotypes. J Oral Microbiol 2013;5:21473. 
7. Haubek D, Dirienzo JM, Tinoco EM, Westergaard J, Lopez NJ, Chung CP, et al. Racial tropism of a highly toxic clone of Actinobacillus actinomycetemcomitans associated with juvenile periodontitis. J Clin Microbiol 1997;35:3037-42.

8. Brogan JM, Lally ET, Poulsen K, Kilian M, Demuth DR. Regulation of actinobacillus actinomycetemcomitans leukotoxin expression: analysis of the promoter regions of leukotoxic and minimally leukotoxic strains. Infect Immun 1994;62:501-8.

9. Punitha T, Moorthy K, Vijayalakshmi P, Vinodhini R, Saranya S, Bhuvaneshwari $\mathrm{M}$, et al. In vitro antibacterial activity of essential plant oils against biofilm forming methicillin-resistant staphylococcus aureus. Asian J Pharm Clin Res 2014;7 Suppl 1:220-5.

10. Nivetha R, Murthy Kumar K, Ashwin KS, Kumar N, Priyadharshini R. Effects of natural products on oral health: a review. Asian J Pharm Clin Res 2014;7:279-82.

11. Subhashini R MH, Geetha RV. The action of tea tree oil and cinnamon leaf oil against oral pathogens. Asian J Pharm Clin Res 2015:8:80-1.

12. Rota MC, Herrera A, Martínez RM, Sotomayor JA, Jordán MJ. Antimicrobial activity and chemical composition of Thymus vulgaris, Thymus zygis and Thymus hyemalis essential oils. Food Control 2008;19:681-7.

13. Chao Sue C, Gary Young D, Craig J. Oberg. Screening for inhibitory activity of essential oils on selected bacteria, fungi and viruses. J Ess Oil Res 2000;12:639-49.

14. Oussalah M, Caillet S, Saucier L, Lacroix M. Antimicrobial effects of selected plant essential oils on the growth of a Pseudomonas putida strain isolated from meat. Meat Sci 2006;73:236-44.

15. Mayaud L, Carricajo A, Zhiri A, Aubert G. Comparison of bacteriostatic and bactericidal activity of 13 essential oils against strains with varying sensitivity to antibiotics. Lett Appl Microbiol 2008;47:167-73.

16. Bouhdid S, Skali SN, Idaomar M, Zhiri A, Baudoux D, Amensour $\mathrm{M}$, et al. Antibacterial and antioxidant activities of Origanum compactum essential oil. Afr J Biotechnol 2008;7:1563-70.

17. Mickiene R, Bakutis B, Baliukoniene V. Antimicrobial activity of two essential oils. Ann Agric Environ Med 2011;18:139-44.

18. Schwiertz A, Duttke C, Hild J, Müller HJ. In vitro activity of essential oils on microorganisms isolated from vaginal infections. Int J Aromather 2006;16:169-74.

19. Si H, Hu J, Liu Z, Zeng ZL. Antibacterial effect of oregano essential oil alone and in combination with antibiotics against extended-spectrum $\quad \beta$-lactamase-producing Escherichia coli. FEMS Immunol Med Microbiol 2008;53:190-4.

20. Hmamouchi M. Les plantes médicinales et aromatiques marocaines, Feddala Edn., Mohammadia; 1999.

21. Kumar R, Srivastava M, Dubey NK. Evaluation of Cymbopogon martinii oil extract for control of postharvest insect deterioration in cereals and legumes. J Food Protect 2007;70:172-8.

22. Kumaran AM, D'souza P, Agarwal A, Bokkolla RM, Balasubramaniam M. Geraniol, the putative anthelmintic principle of Cymbopogon martinii. Phytother Res 2003;17:957.

23. Duke JA, du Cellier J. CRC Handbook of Alternative Cash Crops, Boca Raton: CRC Press; 1993. p. 214.

24. Dorman HJ, Deans SG. Antimicrobial agents from plants: antibacterial activity of volatile plant oils. J Appl Microbiol 2000;88:308-16.

25. Shapiro S, Meier A, Guggenheim B. The antimicrobial activity of essential oils and essential oil components towards oral bacteria. Oral Microbiol Immunol 1994;9:202-8.

26. Hammer KDL, Johnson M, Michalak EM, Carson CF, Riley TV. Susceptibility of oral bacteria to malaleuca alternifolia (tea tree) oil in vitro. Oral Microbiol Immunol 2003;18:389-92.

27. Hammer KA, Carson CF, Riley TV. Antimicrobial activity of essential oils and other plant extracts. J Appl Microbiol 1999;86:985-90.

28. Levison ME. Pharmacodynamics of antimicrobial drugs. Infect Dis Clin North Am 2004;18:451-65.
29. Askun T, Tekwu EM, Satil F, Modanlioglu S, Aydeniz H. Preliminary antimycobacterial study on selected Turkish plants (Lamiaceae) against Mycobacterium tuberculosis and search for some phenolic constituents. BMC Complementary Altern Med 2013;13:365.

30. Bonjar, Shahidi GH. Evaluation of antibacterial properties of Iranian medicinal plants against Micrococcus luteus, Serratia marcescens, Klebsiella pneumoniae and Bordetella broncho septica. Asian J Plant Sci 2004;3:82-6.

31. Durrafourd C, Lapraz JC, Reynier J. Traité de phytothérapie clinique: endobiogénie et médecine, Masson, Paris, France; 2002.

32. Walsh SE, Maillard JY. Activity and mechanisms of action of selected biocidal agents on Gram-positive and negative bacteria. J Appl Microbiol 2003;94:240-7.

33. Lambert RJW, Skandamis PN. A study of the minimum inhibitory concentration and mode of action of oregano essential oil, thymol and carvacrol. J Appl Microbiol 2001;91:453-62.

34. Tyagi R, Sharma G, Dut Jasuja N, Menghani E. Indian medicinal plants as an effective antimicrobial agent. J Crit Rev 2016;3:69-71.

35. Singh D, Kumar TR, Gupt VK, Chaturvedi P. Antimicrobial activity of some promising plant oils, molecules and formulations. Indian J Exp Biol 2012;50:714-7.

36. Schmidt E, Wanner J, Hiiferl M, Jirovetz L, Buchbauer G, Gochev $\mathrm{V}$, Girova, $\mathrm{T}$, et al. Chemical composition, olfactory analysis and antibacterial activity of Thymus vulgaris chemotypes geraniol, 4 thujanol/terpinen-4-ol, thymol and linalool cultivated in southern France. Nat Prod Commun 2012;7:1095-8.

37. Cosentino S, Tuberoso CIG. In vitro antimicrobial activity and chemical composition of Sardinian Thymus essential oils. Lett Appl Microbiol 1999;29:130-5.

38. Joseph B, Priya RM. In vitro antimicrobial activity of psidium guajava 1 . leaf essential oil and extracts using agar well diffusion method. Int J Curr Pharm Res 2010;2:28-32.

39. Chao Sue C, Gary Young D, Craig Oberg J. Screening for inhibitory activity of essential oils on selected bacteria, fungi and viruses. J Ess Oil Res 2000;12:639-49.

40. Oussalah M, Caillet S, Saucier L, Lacroix M. Antimicrobial effects of selected plant essential oils on the growth of a Pseudomonas putida strain isolated from meat. Meat Sci 2006;73:236-44.

41. Mayaud L, Carricajo A, Zhiri A, Aubert G. Comparison of bacteriostatic and bactericidal activity of 13 essential oils against strains with varying sensitivity to antibiotics. Lett Appl Microbiol 2008;47:167-73.

42. Bouhdid S, Skali SN, Idaomar M, Zhiri A, Baudoux D, Amensour M, Abrini J. Antibacterial and antioxidant activities of Origanum compactum essential oil. Afr J Biotechnol 2008;7:1563-70.

43. Kędzia A, Ziółkowska-Klinkosz M, Lassmann Ł, Włodarkiewicz A, Kusiak A, Kochańska B. The susceptibility of microaerophilic bacteria to thyme oil (Oleum Thymi) isolated from infection of oral cavity. Postępy Fitoterapii 2013;3:159-62.

44. Schwiertz A, Duttke C, Hild J, Müller HJ. In vitro activity of essential oils on microorganisms isolated from vaginal infections. Int J Aromather 2006;16:169-74.

45. Fabio A, Cermelli C, Fabio G, Nicoletti P, Quaglio P. Screening of the antibacterial effects of a variety of essential oils on microorganisms responsible for respiratory infections. Phytother Res 2007;21:374-7.

46. Bakkali F, Averbeck S, Averbeck D, Idaomar M. Biological effects of essential oils a review. Food Chem Toxicol 2008;46:446-75.

\section{How to cite this article}

- $\quad$ Leila Lakhdar, Abdellah Farah, Idriss Lahlou, Sana Rida, Amal Bouziane, Oumkeltoum Ennibi. The antibacterial effectiveness of selected moroccan essential oils against the highly virulent JP2 clone of aggregatibacter actinomycetemcomitans. Int J Pharm Pharm Sci 2017;9(2):47-51. 